https://doi.org/10.5800/GT-2017-8-3-0289

\title{
ORE SYSTEMS: TYPES, AND GEODYNAMIC SETTINGS FOR THEIR OCCURRENCE (EASTERN SIBERIA)
}

\author{
Zh. V. Seminsky \\ Irkutsk National Research Technical University, Irkutsk, Russia
}

For citation: Seminsky Zh.V., 2017. Ore systems: types, and geodynamic settings for their occurrence (Eastern Siberia). Geodynamics \& Tectonophysics 8 (3), 553-555. doi:10.5800/GT-2017-8-3-0289.

The Mineralogy, Petrography and Minerals Department of the Irkutsk State Technical University (now the Irkutsk National Research Technical University) has been studying the structural, mineralogical and geochemical features of ore fields for over 30 years. We investigated more than 25 deposits of gold, uranium, rare, non-ferrous and ferrous metals, and published the prognostic metallogenic maps of the ore regions located in Eastern Siberia, Mongolia and Yakutia. Our experience shows that knowing only the genetic characteristics of ore objects is not sufficient for proper metallogenic studies. A complete set of deposit characteristics should include the data on structure, composition, localization conditions and other properties of ore objects and fields. We propose to introduce the "ore system" (OS) concept considering a combination of genetically (paragenetically) related and interrelated petrological, tectonic, metamorphic, mineralogical, geochemical and lithological elements formed during the pre-ore (preparatory) and ore-formation stages [Seminsky, 1990]. In contrast to the proposed OS concept, common terms, such as "ore-magmatic", "oremetasomatic", "ore-generating", "ore-localizing" systems, usually consider only one aspect of the ore process or object [Russian Metallogenic Dictionary, 2003]. In our opinion, descriptions and typification of ore objects viewed as OS should refer to two groups of characteristics.

Main characteristics and types of ore systems. The first group of the mineral deposit characteristics 


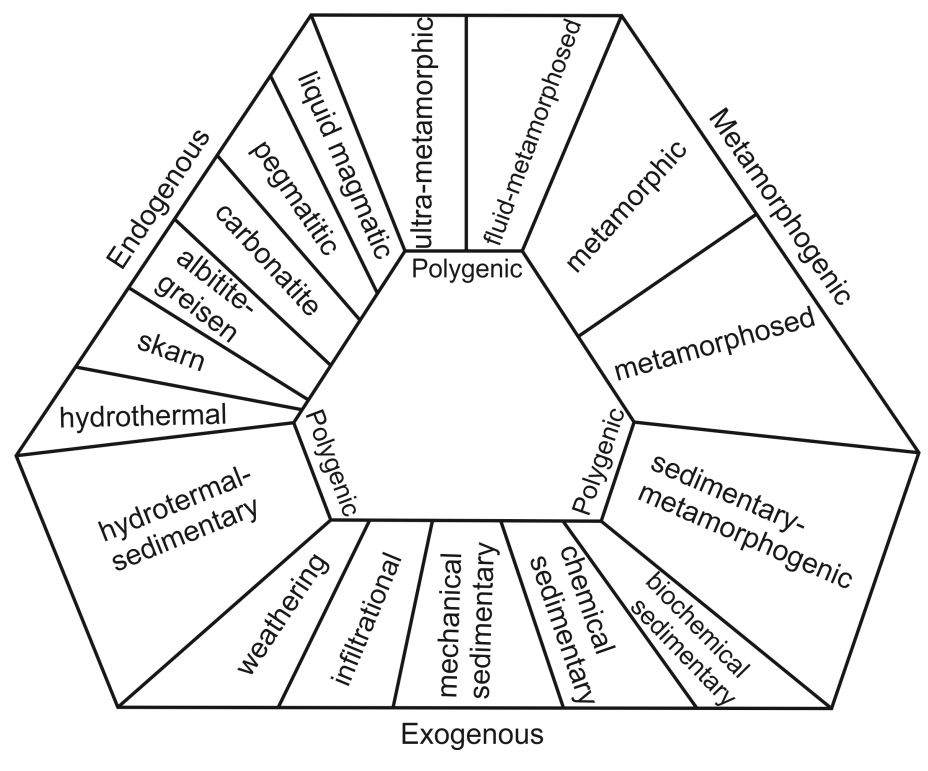

| Genetic classification of mineral deposits.

is genetic. Traditionally, three types of deposits are distinguished: endogenous, exogenous and metamorphogenic. However, more and more studies show the longterm development of ore deposits under the influence of several processes that replace one another as the OS develops. The notions of polygenic and polychromic types of OS are introduced to describe such deposits. For example, the Kuroko OS began to form as hydrothermal and then developed as sedimentary in the seabed setting. In Eastern Siberia, the gold-ore systems (such as, for example, Sukhoi Log) resulted from sedimentation, metamorphism and hydrothermal activity.

Thus, the genetic classification should include not only the three 'main' types of deposits, but also transitional types of polygenic deposits (Figure).

The second group of the OS characteristics is structural-lithological and includes, firstly, tectonic features of OS: structural elements defining the structure of an entire OS, and the locations and shapes of ore bodies, and, secondly, the compositions and properties of host rocks. With account of the types of tectonic dislocations, the plicative, disjunctive and injective ore systems are distinguished. A plicative OS is controlled by similar or concentric folds (Bendigo OS, Australia) or block-type folds (Rudny Altai OS, Russia) or other structural forms. A disjunctive OS is located in a block of fractured rocks (Iulta OS in Yakutia, Russia; Freiberg OS in Germany), or in a fault node (Kadaya OS in Transbaikalia, Russia), etc. An injective OS is located in a plutonic structure (Norilsk OS in sillas and lopolites, Russia), or in a paleocaldera (Streltsovskaya OS, Russia), or in a diatreme (Korshunovskaya OS, Rudnogorskaya RS, Russia).

Geodynamic settings for formation of ore systems. Under the current concepts, the territory of
Eastern Siberia is regarded as a system of orogenic structures that frame the North-Asian craton or the Precambrian and Phanerozoic structures at the margin of the craton. Considering the geological history of this region, most researchers are of the opinion that the region developed in two stages dominated by plate tectonics and plume tectonics, respectively. In the first stage, the Paleo-Asian basin and, later on, the PaleoPacific basins were formed and then closed, and the terranes that differ in origin were gradually attached to the craton. Due to intensive dislocations and magmatism, folded belts were formed, including the belts in the continental margin of the craton. The second stage is related to the development of the Siberian superplume, which involved almost the entire territory in the Late Paleozoic-Mesozoic. Depending on these processes, the following geodynamic settings are distinguished: marginal-craton, collision-accretion, and intraplate plume-tectonic settings [Parfenov, Kuzmin, 2001]. Based on the analysis of the ore systems with respect to various geodynamic settings, it is possible to outline the following trends [Seminsky, 2006].

In the fold-thrust structures of the craton's margin, most typical are magmatogenic ore systems of the pluton-dome type, which are related to mafic-ultramafic complexes (liquid magmatic - $\mathrm{Ti}, \mathrm{Fe}, \mathrm{Cr}, \mathrm{Ni}$ and $\mathrm{Co}$; pegmatitic - $\mathrm{Ta}, \mathrm{Nb}$ and TR; amagmatic (latentmagmatic) fluid-metamorphogenic - $\mathrm{Au}$ and platinum group metals in black shale strata; stratiform type in sandstones - $\mathrm{Cu}$ and $\mathrm{Fe}$; $\mathrm{Fe}$ of quartzites in the zones of metamorphism).

In the accretion-collision geodynamic settings, the following ore systems are most common: stratiform type in the volcanogenic and terrigenous-carbonate strata of synclinal structures - $\mathrm{Pb}, \mathrm{Zn}, \mathrm{Cu}(\mathrm{Fe}, \mathrm{Au})$; veins of the hydrothermal type in the microterranes of the basement - $\mathrm{Au}$; magmatogenic in albitites $-\mathrm{Ta}, \mathrm{Nb}$ and $\mathrm{TR}$; and liquid magmatic - $\mathrm{Ti}, \mathrm{Cu}$ and $\mathrm{Ni}$. In this area, the occurrence of deep ore-bearing objects is most likely related to subduction zones.

In the intraplate geodynamic settings, the ore systems are, as a rule, magmatic. The following types of OS are distinguished: hydrothermal - W, Mo, Be, and Sn; albitite-greisen - Ta, $\mathrm{Nb}$ and TR of the pluton-dome focal structures; hydrothermal - $\mathrm{Au}, \mathrm{Mo}, \mathrm{Pb}$, and $\mathrm{Zn}$; $\mathrm{Ag}$ (with $\mathrm{Au}$ ) of volcano-plutonic and plutonic centers; hydrothermal - U, Mo and fluorite of plutonic and subvolcanic centers; epithermal in the basins - $\mathrm{Au}$ and $\mathrm{Ag}$.

Conclusion. With regard to the processes of formation of ore systems, in addition to the endogenous, exogenous and metamorphogenic groups, we propose to distinguish the group of polygenic ore systems generated due to a combination of various endogenous processes. Based on the types of tectonic dislocations and the structural forms created by them, the ores systems are classified into plicative, disjunctive and injec- 
tive ore systems, and several sub-types. It is established that different ore systems occur in particular geodynamic settings. Abundant ore systems are discovered in the intraplate settings.

\section{REFERENCES}

Russian Metallogenic Dictionary, 2003. VSEGEI Publishing House, St. Petersburg, 320 p. (in Russian).

Seminsky Zh.V., 1990. Genetic models of endogenous-ore systems of Eastern Siberia. In: Geology, exploration and prospecting of ore deposits. University Collection of Papers. Publishing House of the Irkutsk Polytechnical Institute, Irkutsk, p. 6-16 (in Russian).

Parfenov L.M., Kuzmin M.I. (Eds.), 2001. Tectonics, Geodynamics and Metallogeny of the Territory of the Republic of Sakha (Yakutia). Nauka, Moscow, 571 p. (in Russian).

Seminsky Zh.V., 2006. Metallogenic belts of South-Eastern Siberia. Proceedings of the Siberian Department of the Section of Earth Sciences of the RAEN. Geology, Exploration and Development of Mineral Deposits (3), 5-14 (in Russian). 